INVESTIGACIÓN/RESEARCH

\title{
DIGITAL SOCIAL INNOVATION : THE CROWDFUNDING MODEL
}

\author{
Marlene Dulaurans1: University of Bordeaux Montaigne (France) \\ marlenedulaurans@hotmail.com
}

RESUMEN:

Desde el 2004, el fenómeno del crowdfunding encuentra un auge cada vez mayor sobre la web estimulando una nueva forma de economía participativa cerca de los internautas. Se trata de un mecanismo de financiación a través de internet que permite captar fondos del público en general con el fin de apoyar a los portadores de proyectos. 2,7 billones de dólares han transitado en el mundo en el 2012 vía este intermediario. También deseamos interrogarnos en esta contribución sobre esta innovadora iniciativa social inscrita en el corazón mismo de las ciencias de la información y de la comunicación y comprender las razones de este enorme entusiasmo internacional. En primer lugar, este artículo va a cuestionar lo que la innovación digital y este nuevo modelo de financiación participativa representan. Luego se trata de explicar la forma en el que él responde a las necesidades y sectores reales que invierte. Por último, se tratará de aclarar el panorama y las limitaciones de este modelo de cooperación.

PALABRAS CLAVE : Crowdfunding, la innovación social, la economía de colaboración , solidaridad, comunicación, digital.

\section{DIGITAL SOCIAL INNOVATION :}

\footnotetext{
1 Marlene Dulaurans: is an assistant professor in Communication sciences at the University of Bordeaux Montaigne (France). She is an associate researcher in the laboratory of M.I.C.A. (Mediation, Information, Communication, and Art - EA 4426), in the Communication Organizations \& Societies department. Her work focuses on studying new imperatives to cooperate and communicate in organizations and societies in the context of globalization and digital technologies development. She is particularly interested in social media, emerging practices and new forms of social/citizen expression.
} 


\title{
THE CROWDFUNDING MODEL
}

\begin{abstract}
:
Since 2004, the phenomenon of crowdfunding has met a growing development on the web promoting a new form of participative economy to internet users. This is a mechanism of financing via Internet which allows funds to be collected from the general public with the aim of supporting project leaders. 2.7 billion dollars were transited in 2012 worldwide. This article will attempt to analyze this socially innovative initiative ingrained at the heart of communication sciences and to understand the characteristics of such an international phenomenon. First, this paper will question what digital innovation and the new model of participative finance represent. Then we will try to understand and explain how it responds to real expectations and business sectors it invests in. And finally, we will highlight the limitations of such a cooperative model.
\end{abstract}

KEY WORDS: Crowdfunding, social innovation, collaborative economy, solidarity, communication, digital

\section{INTRODUCTION}

The world economy has had profound changes in recent years that undermine competitiveness, growth and employment in many business sectors. Modifying the economic models up to present, the current crisis obliges us to rethink and reconsider particular policies in order to focus on societal issues. New needs arise binding to revise the modes of organization and efficiency of wealth creation. In fact, a new strategy of economic development is emerging based on the capacity of innovation of our societies. Assailing an approach that not only confines itself to its technical dimension, many initiatives appear instead motivated by a philanthropic concern. These social innovations aim at providing effective solutions to social needs poorly satisfied by current conditions of the market. Dominique Lallemand defines social innovation "as a practice that can bring a new questioning, new answers and support different existing or emerging social need. [...] It places people at the center of the process and associates them as possible. It enriches national social policies and allows their development. It develops partnerships and gains meaning " (Lallemand, 2001, p12). Reasoning from this theoretical postulate, the objective of the present work is to tie us to analyze one of its socially innovative initiatives ingrained in in the heart of communication sciences : crowdfunding. This paper will question what digital innovation 
Crowdfunding, la innovación social, la economía de colaboración , solidaridad, comunicación, digital

and the new model of participative finance represent. Then we will try to understand and explain how it responds to real expectations and business sectors it invests in. And finally, we will highlight the limitations of such a cooperative model.

\section{ANALYSIS}

\subsection{From the Statue of Liberty to the Pebble Watch: genesis of crowdfunding}

What are the links between the statue of liberty, Pebble shows or the director Spike Lee? All have in common a social innovation: the funding by the crowd, the principle of "crowdfunding." It is indeed in each case an approach which seeks to raise small amounts money from individuals to fund projects which are clearly identified. While the conditions and procedures for access to conventional financing could easily exhaust and be right out of an incredible talent, even a first vocation, crowdfunding has had an increasing success and offers an alternative to thousands of artists, enthusiasts or entrepreneurs who whish to develop a product, an idea or even to make a living from this activity. What would have become the national monument of the "freedom illuminating the world" on Liberty Island without such an initiative? While the original statue was to be a gift from France to the Universal Exposition in Philadelphia in 1876, the finances allocated were not enough to cover such an investment. A fundraiser was then initiated with the general public, within the press, at shows or banquets, to collect a substantial sum in order to allow its implementation. More than 100000 subscribers then manifested as raising a sum of 400000 francs. A century later, the same need for social innovation remains to respond to social needs and develop new business creation, employment and social cohesion. However, even if the phenomenon continues even today, it has profoundly metamorphosed partially due to the widespread use of NTIC, developing new technological methods. So internet has been the main catalyst of crowdfunding platforms, which is on the same basic principle of pooling of a multitude of individual contributions, to allow an idea or a project from the crowd. If they wish, internet users can then support an initiative by collecting funds with 5, 10, 25, 50 dollars or more. After financing the Statue of Liberty at the end of the 19th century, a platform such as Kickstarter allowed for example in 2013 its unitholders project to materialize and to market the watch Pebble thanks to 10266845 dollars collected from 68929 people or Spike Lee to make his latest film with an amount of 1418 dollars financed by 9106421 contributors. Whether Auguste Bartholdi or an anonymous illustrates, the process of seeking support from the public, the circles of knowledge or the networks unites them beyond the years.

The phenomenon of crowdfunding since 2004 has seen an unprecedented development on the internet worldwide allowing every citizen to become an actor of the project he or she wishes to see evolve. Recent statistics estimate at 536 the number of existing crowdfunding platforms in the world for the year 2012 for a volume of funds raised \$ 2.7 billion: North 
America (59\%) and Europe (35\%) largely dominating the market for this economic model. The first figures of 2013 encourage thinking they could even reach 5.1 billion. Such a will to become emancipated by a classic pyramidal scheme creates in this solidarity a collective financing singular mode of operation in an environment which is empowering. Crowdfunding stands out as a lever frequently used today to raise additional funds by increasing collective engagment around a project which becomes the guarantee of its own success. This shared commitment to implement extends the capabilities of funding between individuals and restores the opportunity for everyone to regain the understanding of a socalled collaborative economy.

For Lisa Gansky " this ease is radically changing the way we organize our lives. Our ultraconnected world allows us to be connected between us, but also to the things that we share collectively » (Gansky, cited by Novel \& Riot, 2010, p 36). A recurring argument is also advanced by many analyzes to justify such a craze around the intercurrence of crowdfunding compared to other existing conventional models. Ricordeau Vincent, cofounder of the platform KissKissBankBank, states that an "economic crisis [which] explains the rapid development of this "new economy". There is a tendency to self bank without going through the conventional manner ( physically to going to banks) due to the crisis and in defiance against traditional banking methods, in other words the economic crisis has empowered some section of the populations. Crowdfunding is thus a genuine alternative to banks". With this in mind, this new kind of finance is divided into three main topics on the web : by field of activity of the platform (culture, health, environmental sustainability, microentrepreneurship...) or by the purpose of financing project or structure), by the form of funding (grant, award, equity, loan...) . The platform provides a general system of suitable payment, legal advice, filtering of members, interactive tools allowing the project leaders to hold informed the internet users of their progress or the contributors to exchange between them... However, if the project presented to users does not reach the financial goal initially fixed, contributors are then fully reimbursed. The platform is self-financed by taking a commission on the total amount raised for each project fully funded (between 5 and 12\%).

\subsection{The "invisible institutions" (Arrow, 1974) of crowdfunding}

Many economists have attempted to analyze the ethical and moral principles which govern the exchanges, quality of social link that determines and influences behavior in society. The digital dimension of crowdfunding accentuates the emergence of new dynamic of network and de facto highlights new relational strategies. They contain various "invisible institutions", characteristics key factors of this new model of participative finance. At first, we could argue that crowdfunding is part of a strong civic commitment allowing each one to become a civic, cultural and economic actor through the web 2.0. Alain Zolty $(2011$, p150) stresses that: " the citizen movement is based on a principle of convergence where it is looked for, not an ideological 
confrontation [...] but a positive consensus by arbitration on the basis of knowledge [of] sustainable and innovative economic activity, [an] ethic of consumption, etc. ». This new practice of crowdfunding reconsiders the active role of individuals in a collective production, offering them the opportunity in this economic model of an egalitarian participation. It represents a new form of co-elaboration in which the search for the common good prevails on the purely personal interests. It asserts itself by the transformation of relations between creators and their environment, encouraging links of cohesion and enhancing the involvement of everyone otherwise than by positioning it in a chain of intermediaries. Crowdfunding also underlies another key principle on the concept of trust. Considered by Simmel as one of the "most important strengths of synthesis within the society", it is loaded of a very high moral value. In the case of crowdfunding, it structures the interactions between individuals by developing a form of moral solidarity. "It has been observed that among other factors that characterize societies whose development is lagging behind, has been described the lack of confidence. [It] which makes it difficult, even impossible, for businesses of all kinds". Although the mechanisms and technological procedures have been established (identification, selection of members, traceability, and repayment of funds under condition...) to limit the risk-taking of the contributor, it remains true the uncertainty in this economic model, emerges as the engine of the granted confidence. Individual motivations fade for the benefit of a conviction of internet users who turns in some cases confidence in a profession of faith. As highlighted earlier on, some projects do not offer any reward in return, compensation or equity participation. Belief in these initiatives therefore requires no proof, only replacing the reason for being and the people at the heart of its concerns. The collective strength also emerges as one of those "invisible institutions" that can be discerned in the model of crowdfunding. Following the example of what Henri Nicolas Verdier and Colin (2012, introduction) points that «projects thrive in a world where technology costs continue to decline, where innovation is accelerating: a hyperfluid world. It is a world in which individuals have a power of creation, of unprecedented communication and coordination forming a creative community, connected and mobile to the multitude». It is through the sharing of singularities and the collective power that it engages, that participative finance can enable a project to develop according to the required needs. It captures, collects and coordinates individuals serving a better digital action. This collective force asserts for the project a structural representation of the group and tends in this context to create a mutual emulation with contributors (percentage reaches of the collected funds, number of hours remaining before the end of the online project...). Finally the last crowdfunding discloses a key feature : the ability of the surprise (in the Aristotelian sense) of internet users in front of innovation. This economic model opts for a mindset that encourages risk-taking and inventiveness constantly sharpening the curiosity of contributors. It actually creates a favorable climate to initiative. Participative finance establishes a culture of discovery and maintains a constant taste for innovation and experimentation. It allows to stay on alert in front of a hot environment in which creativity and continuous involvement of internet users are closely related. This capacity of surprise at innovation recovers " more of a behavior, of an attitude, of a mindset, of an ability to use its experience as a special know-how » (Lallemand, 2001, 
$\mathrm{p}$ 60). It appears as one of the determining factors reflecting the significant growth experienced by different dedicated platforms.

\subsection{Crowdfunding also attracts research}

Many platforms such as Kickstarter (across the Atlantic) or MyMajorCompagny (France) have been very successful these last years, popularizing the model of crowdfunding to the general public, particularly in cultural creation. Several artists have been discovered on the web and propelled into the public arena financed by the crowd of internet users. Although very much present, within the music industry it does not monopolize most of the existing platforms, some dedicating themselves within the business industry, supportive, or environmental issues (Ecobole, Bodegga, FriendsClear, Babyloan Spear WiSeed, Reservoir Funds...). However, there is a surprising area where crowdfunding makes a convenient arrival: research. In fact, not benefiting from public finance or private funds to develop projects deemed not rather attractive or unprofitable for universities or states, some researchers and laboratories are turning enthusiastically to this new economic model. The example in France confirms this established fact, the current conditions of French universities are considered to be of concern by senior government officials : "Between 10 and 15 are in deficit for the second consecutive year, half no longer have extra funds to run their universities and a quarter of them have a negative cash flow » (Vogel, 2012, proceedings of the workshop). Facing such a report, alternatives had to be found in some cases so that the research mission can be brought to a successful conclusion. For example on the Indiegogo platform in April 2013 a Moldovan PhD student enrolled in humanities and social sciences at the University of Strasbourg launched a crowdfunding campaign to help her finish to finish her research work "in an honest way". As she didn't have a scholarship or a grant (in France only $10 \%$ of doctoral students in the humanities receive a research allowance - the dropout rate of thesis is around $60 \%$ ), so she used charity contributions of internet users to raise the necessary funds to cover the costs of her last year of writing. The initial amount she needed was set at $\$ 5,230$. In one month, she reached the sum of $\$ 6,849$ an objective goal reached by more than $130 \%$. This initiative in France finds another echo across the Atlantic Ocean, where researchers seize the opportunity of crowdfunding to finance scientific projects in their entirety. Specialized platforms were only created with this single purpose (Microryza, Petridish.Org, Fundageek, Scifundchallenge...). Contributors fund scientific experiments and are informed about the advance of the project, about the progress made during the research and about the obtained results. In some cases, they can even participate in the expeditions, in person. While we would expect that only traditional sciences benefit from such a system (only $25 \%$ of thesis are made in humanities), social sciences now also earn the favor of internet user, in particular through projects in history, in education, in psychology...

\subsection{An economic model which reaches its limits}

The growth experienced of crowdfunding provided today raises many questions and suggests that this model, both by its nuances and its approaches, raises first of all ethical 
Crowdfunding , la innovación social, la economía de colaboración , solidaridad, comunicación, digital

questions. Indeed, although recent on the web and popular for its novelty, many projects still see this concept of collaborative economy suspiciously. Participative finance contains a significant element of risk for contributors. It raises the problem of the quick decision-making of the internet user, leaving him or her not much time to verify the strength and the validity of the project in which he or she can potentially invest his or her money. Although some explanations are provided on platforms (goals and outcomes), the investment remains opaque and difficult to identify concrete, coherent and hierarchical elements of business plan such as the team and coaching, the analysis market, the marketing strategy referred, means and organization spread... The contributor has no choice but to trust the project and to hope that it delivers the expected results. But all crowdfunding campaigns do not lead to much. Some of them do not reach their initial fundraising goal. For example, on the Kickstarter platform, $90 \%$ of campaigns that fail do not obtain $30 \%$ of the targets. Beyond not achieving the outcome of the project (and thus the repayment of contributors who participated in the unfinished collection within the time limits allowed), crowdfunding may present a risk to the unfortunate investor who has no guarantee of the expenditure of his or her funds. The platform, positions itself only as an intermediary between the provider and the recipient of fund, and therefore cannot protect against any risk of embezzlement and fraud. The second limitation encountered in the development of the economy of sharing reports of legal issues. In the absence of a clear regulatory framework particularly in France, the legislation is complex for various stakeholders. Without providing a specific answer, it begins to question the privacy of projects and to raise the thorny issue of intellectual property. In parallel, it puts under debate the question of the respect of the contract between the parties in case the results obtained on a project funded in a collaborative manner would not be in accordance with those originally presented to contributors (basis on which they made a commitment) . Concerning the domain of entrepreneurship, the banking and the tax regulations also restrict certain project leaders, either in the number of the qualified investors or in the dissemination of confidential information if they do not want to be subject to the obligations of the AMF public offering2. Platforms must now engage in a substantive work for the credibility of the crowdfunding model and convince potential internet users to fund projects more supervised and regulated.

Finally, questions of financial order is also needed within this discourse, opened by the development of crowdfunding on the web. MyMajorCompany was one of the first platforms to venture into its trade policy and to have to quickly readjust its system which aimed at allowing contributors to become producers and thereby to see putting back profits on sales made by artists. While this prospect is promising and has encouraged many internet users to finance artistic projects, the reality of facts was quite different and demonstrated that few of them really succeeded, creating a growing discontent among providers of funds swindled by the bait of the hoped gains. The platform then had to reposition itself as a simple intermediary entrusting to every project leader the care of managing oneself the collected

2 Official name : «L'Autorité des Marchés Financiers de l'appel public à l'épargne » 
funds. Other striking examples of participative finance have also shown that it is not still adapted to carry industrial projects which require a significant fundraising. The project of the high-end smartphone, Ubuntu Edge, launched last month on the Indiegogo platform has demonstrated the limits of such an economic model. Hoping to raise \$ 32 million, the Canonical company only collected $\$ 12.8$ million and was not able to throw the production of the product. A positive aspect stands out from this failure : participative enthusiasm for this project confirmed that customers $(27,634$ identified contributors) for this product existed. To avoid such a situation and that a project is interrupted because the fundraising is slowing a few days before the deadline, some project leaders have exploited the principle of crowdfunding, that is developping a project with the participation of internet users, by deciding to add themselves the necessary sum of money to reach the financial objective of departure. This maneuver, that may appear doubtful, aims at not losing the money invested by others, even if it does not represent the total funds required : the purpose is primarily the realization of the project.

\section{CONCLUSION}

The field of social innovation remains a vast arena to explore where there is not a single approach to encourage and support it. We have seen that the model of crowdfunding in the current market conditions but also in the actual funding policies conducted, can answer a new social need, disintermediation and collaborative. It contributes to establish an incentive environment which is constantly changing and involves a multitude of actors. Although it seems limitless because of the variety of projects it helps to finance, however it confronts with certain legal, financial and ethical limits that constrain and moderate its development, what are largely aware the founders of these participatory finance platforms : "Financial crisis has speed up looking for alternatives. Crowdfunding is a solution but not the solution. We need many more. Businesses will rely on some crowdfunding in the future [...] It is easy to do, it is beneficial to do it so it makes sense. But it's far to be the new antidote » (Marot, 2012, p 41). 
Crowdfunding , la innovación social, la economía de colaboración , solidaridad, comunicación, digital

\section{BIBLIOGRAPHIY}

ARROW, Kenneth Joseph. (1974). The limits of organization. New York, Norton.

GANSKY, Lisa. (2010) The Mesh: Why the Future of Business Is Sharing. New York. Penguin Group US. In NOVEL, Anne-Sophie. RIOT, Stéphane. Vive la corévolution !. Paris. Alternatives éditions.

GIDDENS, Anthony. (2007) Les conséquences de la modernité. Paris. Editions L'Harmattan.

LALLEMAND, Dominique. (2001), Les défis de l'innovation sociale. Paris. Esf Editeur.

LAURENT, Éloi. (2012). Économie de la confiance. Paris. La Découverte.

MAROT, Florent. (October 2012). Le crowdfunding finance tout et n'importe qui. Bruxelles. IHECS Report.

SIMMEL, Georg. (2010). Sociologie : Etudes sur les formes de la socialisation. Paris. Presses Universitaires de France.

VERDIER, Henri. COLIN, Nicolas. (2012). L'âge de la multitude: Entreprendre et gouverner après la révolution numérique. Paris. Armand Colin.

ZOLTY, Alain. (2011). L'espoir citoyen: Manifeste pour une nouvelle gouvernance. Paris. Editions L'Harmattan.

WEBOGRAPHY

Visual.ly. (2013). Crowdfunding Statistics and Trends. Available at : http://visual.ly/crowdfunding-statistics-and-trends. Consulted on August 29, 2013.

Céreq. (2013). Etude du Céreq. Available at : http://www.collectifpapera.org/spip.php?article679. Consulted on August 29, 2013.

HUSSON, Laure-Emmanuelle. (2012). Le crowdfunding ou comment financer un projet sans l'aide d'une banque. Challenges. Available at : http://www.challenges.fr/entreprise/20120628.CHA8209/le-crowdfunding-ou-commentfinancer-un-projet-sans-l-aide-d-une-banque.html. Consulted on August 29, 2013. 
Indiegogo. (2013). Moldova, mon amour!. Available at : http://www.indiegogo.com/ projects/moldova-mon-amour. Consulted on August 29, 2013.

Kickstarter. (2013). Pebble: E-Paper Watch for iPhone and Android. Available at : http://www.kickstarter.com/ projects/597507018/pebble-e-paper-watch-for-iphone-andandroid?ref=most-funded. Consulted on August 29, 2013.

Kickstarter. (2013). The Newest Hottest Spike Lee Joint. Available at : http://www.kickstarter.com/ projects/spikelee/the-newest-hottest-spike-lee-joint. Consulted on August 29, 2013.

Indiegogo. (2013). Ubuntu Edge. Available at : http://www.indiegogo.com/ projects/ubuntu-edge. Consulted on August 29, 2013.

VOGEL, Louis. (2012). Discours à la Conférence des Présidents d'universités. Available at: http://www.cpu.fr/Colloque_annuel_2012.1310.0.html. Consulted on August 29, 2013. 